Another division of experimental work at the Farm put up scare-crows on the range next to the demonstration plots thus chasing the blackbirds into the cereal variety tests where a great deal of damage was done. Damage was particularly severe in 1961 because of the thin crops and increased number of birds.

As long as the blackbirds get all the ripening grain they can eat near their nesting area they will leave experimental plots alone. However, sunflowers are the exception. If there are sunflowers within a mile or two the blackbirds will feed on them in preference to grain crops. The only way to grow sunflower variety tests is the tedious covering of each head after it flowers with a waxedpaper garbage bag. Even then the birds tear some bags and get at the maturing heads.

While the provision of lure or feeding strips seems to be the most prac- tical means of preventing damage, it is not positive. For this reason the high voltage apparatus will be maintained for the most valuable material. In addition the Experimental Farm is planning to invest in acetylene exploders and strings of firecrackers which can be used as emergency measures. These make a loud bang every few minutes and provide a continuous scare.

By combining a number of methods of preventing crop damage it maý be possible for us to live in harmony with the yellow-headed birds. Who knows, we may even learn to appreciate their aesthetic value!

\section{LITERATURE CITED}

Grant, M. N., and S. A. Wells. 1957. Bird damage control at Lethbridge. Cereal News, 3 (1): 5-8

Pfeifer, P. 1956. A bird control apparatus for experimental plots. Agron. Jour., 48: 139141.

\title{
Mockingbird at Fort Qu'Appelle
}

\author{
by E. M. Callin, Fort San
}

I suppose most bird-watchers have a few "check-points"-good spots that are most accessible and can be visited even if only a few minutes are available. They are especially useful and rewarding during migration.

One of my favourite check-points is the dam over the river at Fort Qu'Appelle for there, in a very small space, are river, lake, marsh, large trees and shrubs. On May 18, 1962, as I made a detour to this area, a bird flew up in front of the car and settled in some near-by willows. The unusual pattern and shape of the wings and tail immediately marked it as a stranger and moments later I was viewing through my binoculars the first.Mockingbird I had ever seen. At first it was lightly screened by the willows but during the next ten minutes or so I had an unobstructed view as it moved from tree to tree, then flew to the ground and proceeded to feed.

The actions of the bird while ground feeding were quite interesting and unusual; each time it moved forward the wings were spread and raised to the approximate level of the back. Though a pale and comparatively colorless bird when at rest, a surprising transformation occurred when the expanded wings flashed boldly with white. In this respect it reminded one of the Willet and of the Shrikes.

The Mockingbird is a rarity in Saskatchewan. There are few records for the province and, although I have records of over 20 observers in respect for the Qu'Appelle-Valley and adjoining area, with some of the records dating back for 100 years, there are yet only four records for this area (all of them within the last five years).

\section{EARLY RECORD OF GYRFALCON NEAR REGINA}

by Thomas E. Randall, Edmonton

The following old note from my journal may be worth recording. On December 12, 1912, while I was crossing a field on our farm four.miles from Drinkwater (about 25 miles southwest of Regina) a white-phase Gyrfalcon flew over my head so close that the black spotting could be clearly seen. 